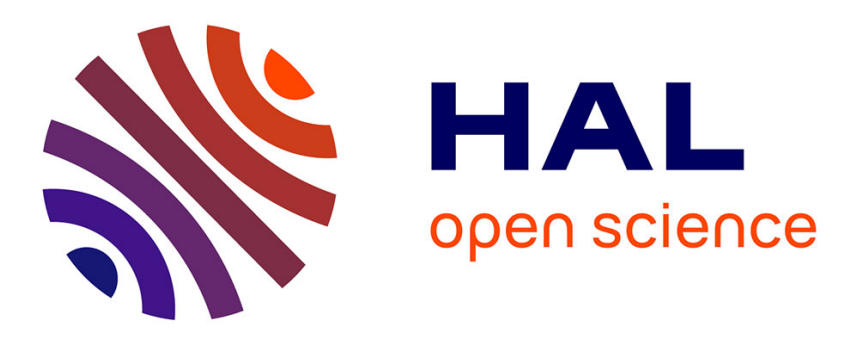

\title{
Lanthanide coordination polymers with 1,2-phenylenediacetate
}

Insa Badiane, Stéphane Freslon, Yan Suffren, Carole Daiguebonne, Guillaume Calvez, Kevin Bernot, Magatte Camara, Olivier Guillou

\section{- To cite this version:}

Insa Badiane, Stéphane Freslon, Yan Suffren, Carole Daiguebonne, Guillaume Calvez, et al.. Lanthanide coordination polymers with 1,2-phenylenediacetate. Inorganica Chimica Acta, 2017, 461, pp.136-144. 10.1016/j.ica.2017.02.012 . hal-01477155

\section{HAL Id: hal-01477155 https://hal.science/hal-01477155}

Submitted on 5 Jul 2017

HAL is a multi-disciplinary open access archive for the deposit and dissemination of scientific research documents, whether they are published or not. The documents may come from teaching and research institutions in France or abroad, or from public or private research centers.
L'archive ouverte pluridisciplinaire HAL, est destinée au dépôt et à la diffusion de documents scientifiques de niveau recherche, publiés ou non, émanant des établissements d'enseignement et de recherche français ou étrangers, des laboratoires publics ou privés. 


\section{Lanthanide coordination polymers with 1,2-}

\section{phenylenediacetate.}

Insa Badiane ${ }^{\mathrm{a}, \mathrm{b}}$, Stéphane Freslon ${ }^{\mathrm{a}}$, Yan Suffren ${ }^{\mathrm{a}}$, Carole Daiguebonne ${ }^{\mathrm{a}}$, Guillaume Calvez ${ }^{\mathrm{a}}$, Kevin Bernot ${ }^{\mathrm{a}}$, Magatte Camara ${ }^{\mathrm{b}}$ and Olivier Guillou ${ }^{\mathrm{a}}$.

a INSA Rennes, UMR 6226 “Institut des Sciences Chimiques de Rennes”, F-35708 Rennes

${ }^{\mathrm{b}}$ Université Assane Seck de Ziguinchor, LCPM - Groupe "Matériaux Inorganiques : Chimie Douce et Cristallographie". BP. 523 Ziguinchor - Sénégal

* To whom correspondence should be addressed 


\section{ABSTRACT.}

Reactions in water between lanthanide chlorides and the di-sodium salt of 1,2phenylenediacetic acid, $\mathrm{Na}_{2}(\mathrm{o}-\mathrm{pda})$, lead to two families of coordination polymers with respective chemical formulae $\left[\mathrm{La}_{2}(\mathrm{o}-\mathrm{pda})_{3}\left(\mathrm{H}_{2} \mathrm{O}\right)_{4}, 4 \mathrm{H}_{2} \mathrm{O}\right]_{\infty}(\mathbf{1})$ and $\left[\mathrm{Ln}_{2}(\mathrm{o}-\mathrm{pda})_{3}\left(\mathrm{H}_{2} \mathrm{O}\right)_{2}, 2 \mathrm{H}_{2} \mathrm{O}\right]_{\infty}$ (2) for $\mathrm{Ln}=\mathrm{Ce}-\mathrm{Nd}, \mathrm{Sm}-\mathrm{Lu}$ and $\mathrm{Y}$. Compound $\mathbf{1}$ crystallises in the monoclinic system, space group $C 2 / c\left(\mathrm{n}^{\circ} 15\right)$, with $a=28.195(5) \AA, b=12.2305(3) \AA, c=8.7607(1) \AA, \beta=98.835(1)^{\circ}$ and $Z=4$. Its crystal structure and thermal properties are described. Compounds of family 2 are isostructural to a previously reported crystal structure. Luminescence properties of Euand $\mathrm{Tb}$-based compounds have been studied.

KEYWORDS: Lanthanide $\cdot$ Coordination polymer - Crystal structure $・$ Luminescence $•$ Energy Transfer 


\section{INTRODUCTION.}

Lanthanide coordination polymers have been studied for almost two decades ${ }^{[1]}$ because of their application ${ }^{[2,3]}$ in gas storage ${ }^{[4-13]}$, catalysis ${ }^{[14]}$, separation ${ }^{[15]}$, luminescence ${ }^{[16-}$ ${ }^{25]}$ and molecular magnetism ${ }^{[26-29]}$. Our group is involved in this field ${ }^{[30-34]}$. The search for new ligands that could lead to new structural network and/or new physical properties is ongoing $^{[35,36]}$. To date our attention has been mainly focused on phenyl-poly-carboxylate ligands such as melitate ${ }^{[37]}$, pyromelitate ${ }^{[38]}$ trimesate $^{[39]}$, terephthalate ${ }^{[32]}$ or iso-phthalate ${ }^{[19]}$. All these ligands are rigid extended $\pi$-systems. On the opposite, 1,2-phenylenediacetate (See Scheme 1) has flexible $-\mathrm{CH}_{2}$ - groups that cut conjugation and allow free rotation of the carboxylate functions.<smiles>O=C([O-])Cc1ccccc1CC(=O)[O-]</smiles>

Scheme 1. 1,2-phenylenediacetate ligand (o-pda) ${ }^{2-}$.

Some coordination polymers based on this ligand, often together with another rigid ligand, have been reported with transition metal ions ${ }^{[40-43]}$. To our knowledge, to date, there is only one crystal structure of lanthanide coordination polymers that involves only this ligand. This crystal structure, that corresponds to compounds with chemical formula [ $\operatorname{Ln}_{2}(\mathrm{o}-$ pda $\left.)_{3}\left(\mathrm{H}_{2} \mathrm{O}\right)_{2}, 2 \mathrm{H}_{2} \mathrm{O}\right]_{\infty}$ has been reported four times with different lanthanide ions: $\mathrm{Ln}=\mathrm{La}$ $\left(\right.$ CCDC-952811), Nd $(\text { CCDC-953279 })^{[44]}, \mathrm{Ln}=$ Dy $(\text { CCDC-669663 })^{[45]}, \mathrm{Ln}=\operatorname{Pr}(\mathrm{CCDC}-$ 963495), Er (CCDC-963497) ${ }^{[46]}$ and Ln = Tb (CCDC-635048), Ho (CCDC-635081) $)^{[47]}$. These compounds crystallise in the monoclinic system, space group $C 2 / c\left(\mathrm{n}^{\circ} 15\right)$. Their cell parameters are summarised in Table S1. In this crystal structure, there is only one independent 
$\mathrm{Ln}^{3+}$ ion that is nine coordinated by eight oxygen atoms from six (o-pda) $)^{2-}$ ligands and one oxygen atom from a coordination water molecule (Figure 1). The two (o-pda) ${ }^{2-}$ ligands bridge the $\mathrm{Ln}^{3+}$ ions to form a 3D framework (Figure 1).
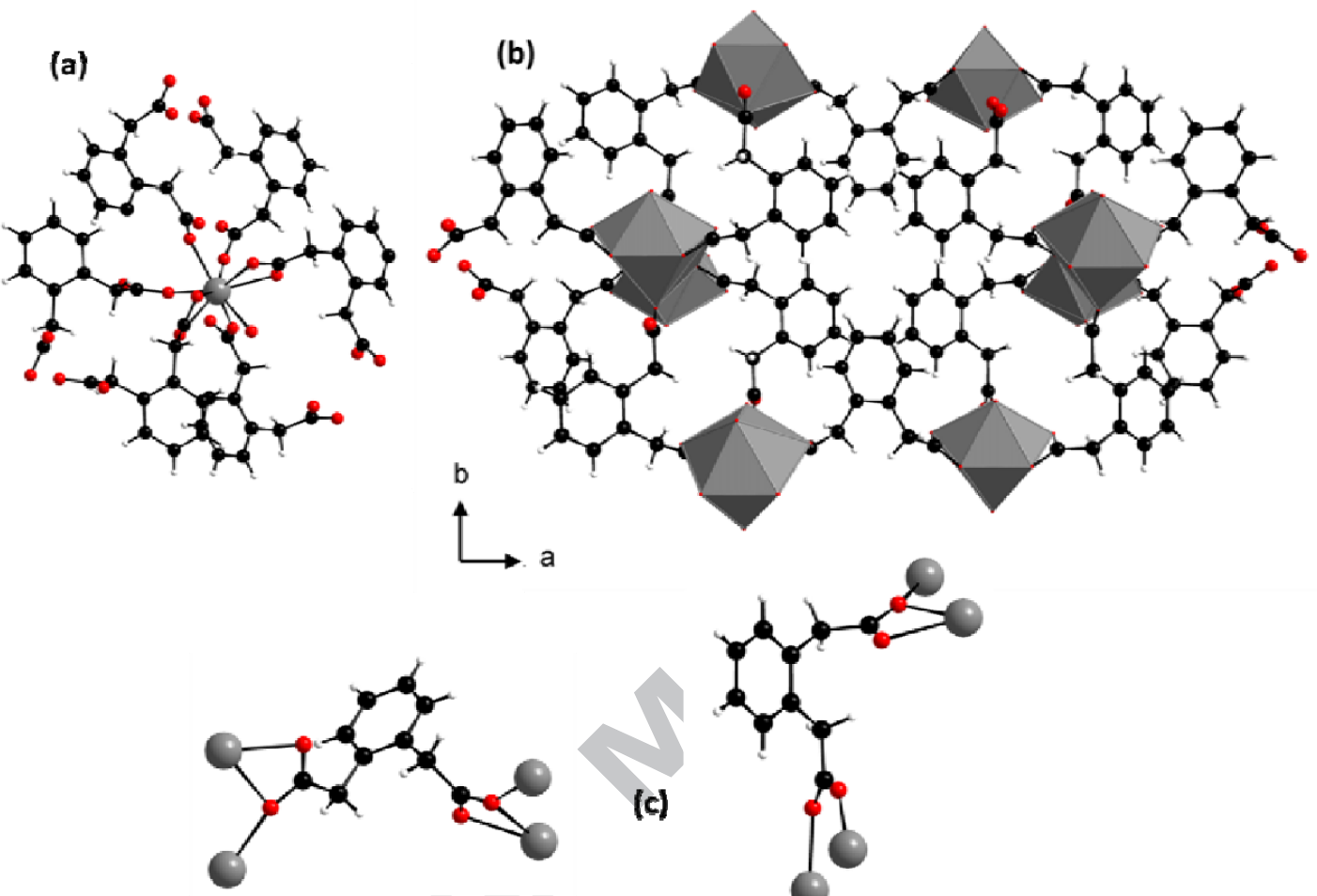

(c)

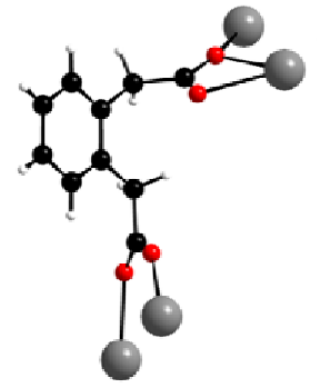

Figure 1. (a) Projection view of the coordination of a $\mathrm{Tb}^{3+}$ ion in $\left[\mathrm{Tb}_{2}(\mathrm{o}-\mathrm{pda})_{3}\left(\mathrm{H}_{2} \mathrm{O}\right)_{2}, 2 \mathrm{H}_{2} \mathrm{O}\right]_{\infty}$. (b) Perspective view along the $\mathrm{c}$ axis of the crystal packing of $\left[\mathrm{Tb}_{2}(\mathrm{o}-\mathrm{pda})_{3}\left(\mathrm{H}_{2} \mathrm{O}\right)_{2}, 2 \mathrm{H}_{2} \mathrm{O}\right]_{\infty}$. (c) Projection view of the penta-dentate (right) and hexa-dentate (left) o-pda ${ }^{2-}$ ligands in $\left[\mathrm{Tb}_{2}(\mathrm{o}-\right.$ pda $\left.)_{3}\left(\mathrm{H}_{2} \mathrm{O}\right)_{2}, 2 \mathrm{H}_{2} \mathrm{O}\right]_{\infty}$. Redrawn from reference [47].

The scarcity of the reported crystal structures in the system $\mathrm{Ln}^{3+} /(\mathrm{o}-\mathrm{pda})^{2-}$ led us to reinvestigate it using growth of single-crystals in gels. Indeed, all the previously reported compounds were obtained by hydrothermal synthesis. Crystallisation in gels has already proved its efficiency as far as new crystal structures are targeted ${ }^{[48]}$. Micro-crystalline powders were prepared by direct precipitations in water because this green and convenient method is interesting for technological transfer. 


\section{EXPERIMENTAL SECTION.}

\section{Preparation of the starting salts.}

Lanthanide oxides (99.99\%) were purchased from AMPERE company. Lanthanide chloride have been synthesised according to literature ${ }^{[49]}$.

Phenylenediacetic acid, $\mathrm{H}_{2}$ (o-pda), from Sigma-Aldrich was used without purification. Its di-sodium salt has been prepared by addition of two equivalents of sodium hydroxide to a suspension of the acid in deionised water. The obtained clear solution has been evaporated to dryness and then refluxed in ethanol for one hour. Addition of diethylether precipitates $\mathrm{Na}_{2}(\mathrm{O}-$ pda) in $90 \%$ yield. TG analysis indicates that this salt is anhydrous. Elemental analysis of $\mathrm{C}_{10} \mathrm{H}_{8} \mathrm{O}_{4} \mathrm{Na}_{2}\left(\mathrm{MW}=234\right.$ g.mol $\left.{ }^{-1}\right)$ : Calculated (Found): C 50.2\% (50.4\%); H 3.5\% (3.4\%); O $27.0 \%(26.9 \%) ; \mathrm{Na} 19.3 \%(19.3 \%)$.

IR spectrum of the salt in $\mathrm{KBr}$ pellets, shows no characteristic band of protonated carboxylic acid (1715-1680 $\left.\mathrm{cm}^{-1}\right)$ which suggests complete de-protonation of the ligand. UVvis absorption spectrum of a $4.410^{-4}$ mol... $\mathrm{L}^{-1}$ aqueous solution of the di-sodium salt has been measured with a Perkin-Elmer Lambda 650 spectrometer equipped with a $60 \mathrm{~mm}$ integrating sphere (Figure S1). It shows a maximum absorption at $262 \mathrm{~nm}\left(\varepsilon_{\max }=240 \mathrm{~L} \cdot \mathrm{mol}^{-1} \cdot \mathrm{cm}^{-1}\right)$. This short wavelength of absorption can be related to the $-\mathrm{CH}_{2}$ - groups that cut conjugation.

\section{Synthesis of the single crystals.}

Tetramethylorthosilicate (TEOS), from Acros Organics, was used without purification.

It was jellified according to literature ${ }^{[48,50,51]}$. Dilute aqueous solutions $\left(0.1 \mathrm{~mol}^{-\mathrm{L}^{-1}}\right)$ of lanthanide chloride on one hand and of $\mathrm{Na}_{2}(\mathrm{O}-\mathrm{pda})$ on the other hand were allowed to slowly diffuse through a gel (7.5 volume percent of TEOS in water) in U-shaped tubes at room temperature. After a few weeks plate-like single crystals suitable for X-ray structure determination were obtained. 


\section{Syntheses of the microcrystalline powders.}

Microcrystalline powders of homo-metallic compounds were obtained by mixing, at room temperature, aqueous solutions that contain respectively stoichiometric amounts of lanthanide chlorides ( $1 \mathrm{mmol}$ in $20 \mathrm{~mL}$ of deionised water) and $\mathrm{Na}_{2}$ (o-pda) (1.5 mmol in 20 $\mathrm{mL}$ of deionised water). Precipitation immediately occurred. The mixtures were filtered and rinsed with water. The product was dried in air. The yields were close to $90 \%$. The chemical analyses are in Table $\mathrm{S} 2$.

The lanthanum-based compound has been assumed to be iso-structural to $\left[\mathrm{La}_{2}(\mathrm{O}-\right.$ pda $\left.)_{3}\left(\mathrm{H}_{2} \mathrm{O}\right)_{4}, 4 \mathrm{H}_{2} \mathrm{O}\right]_{\infty}(\mathbf{1})$ on the basis of its powder X-ray diffraction (Figure S2). Its crystal structure is described here.

Compounds obtained with a lanthanide ion from cerium to lutetium (except promethium) and yttrium have been assumed to be iso-structural to the reported crystal structure on the basis of their powder X-ray diffraction (Figure S3). Cell parameters of the compounds of this series have been refined from their powder X-ray diffraction (Figure S4). In the literature, the number of crystallised water molecules in this crystal structure varies from 2 to 2.5 per formula unit. Thermo-gravimetric analyses that we have performed support the presence of 2 crystallised water molecules per formula unit (Figure S5). Therefore, compounds that constitute this family have general chemical formula [ $\operatorname{Ln}_{2}(0-$ pda $\left.)_{3}\left(\mathrm{H}_{2} \mathrm{O}\right)_{2}, 2 \mathrm{H}_{2} \mathrm{O}\right]_{\infty}$ with $\mathrm{Ln}=\mathrm{Ce}-\mathrm{Nd}, \mathrm{Sm}-\mathrm{Lu}$ and $\mathrm{Y}(\mathbf{2})$.

Microcrystalline powders of hetero-bi-metallic compounds have been obtained in a similar procedure by using the appropriate mixture of lanthanide chloride solutions in the synthesis. Two series of compounds have been prepared with respective chemical formulae $\left[\mathrm{Tb}_{2 \mathrm{x}} \mathrm{Gd}_{2-2 \mathrm{x}}(\mathrm{o}-\mathrm{pda})_{3}\left(\mathrm{H}_{2} \mathrm{O}\right)_{2}, 2 \mathrm{H}_{2} \mathrm{O}\right]_{\infty}$ with $0 \leq \mathrm{x} \leq 1$ and $\left[\mathrm{Tb}_{2 \mathrm{x}} \mathrm{Eu}_{2-2 \mathrm{x}}(\mathrm{o}-\mathrm{pda})_{3}\left(\mathrm{H}_{2} \mathrm{O}\right)_{2}, 2 \mathrm{H}_{2} \mathrm{O}\right]_{\infty}$ with $0 \leq \mathrm{x} \leq 1$. These compounds have been assumed to be isostructural to the homo-metallic 
compounds on the basis of their powder X-ray diffraction (Figures S6 and S7). Cell parameters have been refined on the basis of the X-ray powder diffraction (Figures S8 and S9). These diagrams indicate a random distribution of the lanthanide ions in the metal sites of the crystal structure ${ }^{[52]}$. Relative ratios of the lanthanide ions have been measured by EDS (Tables S3 and S4).

\section{Powder X-ray diffraction.}

The diagrams have been collected using a PanalyticalX'Pert Pro diffractometer equipped with an $X^{\prime}$ Celerator detector. Calculated patterns were produced using POWDERCELL and WINPLOTR software programs ${ }^{[33,54]}$. Pattern indexing was performed by MACMAILLE program ${ }^{[5]}$ and refinement of the unit cell parameters by means of CHECKCELL program from CRYSTFIRE suite ${ }^{[56]}$

Temperature-dependent X-ray diffraction diagrams have been produced with the same diffractometer. The samples were heated from room temperature to $1000^{\circ} \mathrm{C}$ using an Anton Parr HTK 1200 furnace under nitrogen atmosphere.

\section{Single crystal X-ray diffraction.}

Single crystals of $\left[\mathrm{La}_{2}(\mathrm{o}-\mathrm{pda})_{3}\left(\mathrm{H}_{2} \mathrm{O}\right)_{4}, 4 \mathrm{H}_{2} \mathrm{O}\right]_{\infty}$ (1) were mounted on a Kappa CCD Bruker diffractometer with Mo K $\alpha$ radiation $(\lambda=0.71073 \AA)$. Crystal data collection has been performed at room temperature. Data reduction and cell refinement were performed with Denzo and Scalepack programs ${ }^{[57]}$. The crystal structure has been solved by direct methods using SIR97 program ${ }^{[58]}$, and refined with full matrix least-square methods based on $\mathrm{F}^{2}$ (SHELX97 $^{[59]}$ ) with WINGX program ${ }^{[60]}$. All non-hydrogen atoms were refined anisotropically using SHELXL program. Hydrogen atoms of the organic ligand were located at ideal positions. Hydrogen atoms of the water molecules were not located. Crystal and final 
structure refinement data of $\left[\mathrm{La}_{2}(\mathrm{o}-\mathrm{pda})_{3}\left(\mathrm{H}_{2} \mathrm{O}\right)_{4}, 4 \mathrm{H}_{2} \mathrm{O}\right]_{\infty}(\mathbf{1})$ are in Table 1. Full details of the X-ray structure determination of $\left[\mathrm{La}_{2}(\mathrm{o}-\mathrm{pda})_{3}\left(\mathrm{H}_{2} \mathrm{O}\right)_{4}, 4 \mathrm{H}_{2} \mathrm{O}\right]_{\infty}(\mathbf{1})$ have been deposited with the Cambridge Crystallographic Data Center under the depository number CCDC-1495169 and can be obtained free of charge at http://www.ccdc.cam.ac.uk/conts/retrieving.html [or from the Cambridge Crystallographic Data Centre, 12, Union Road, Cambridge CB2 IEZ, UK; fax: (internat.) +44-1223/336-033; E-mail: deposit@ccdc.cam.ac.uk], on request, from the authors and the reference to this publication.

\begin{tabular}{ll}
\hline $\begin{array}{l}\text { Table 1. Structure refinement data for } \\
{\left[\mathrm{La}_{2}(\mathrm{o}-\mathrm{pda})_{3}\left(\mathrm{H}_{2} \mathrm{O}\right)_{4}, 4 \mathrm{H}_{2} \mathrm{O}\right]_{\infty}(\mathbf{1})}\end{array}$ \\
\hline Molecular formula & $\mathrm{La}_{2} \mathrm{C}_{30} \mathrm{H}_{20} \mathrm{O}_{40}$ \\
System & $\mathrm{Monoclinic}$ \\
$a(\AA)$ & $28.195(5)$ \\
$b(\AA)$ & $12.2305(3)$ \\
$c(\AA)$ & $8.7607(1)$ \\
$\beta\left({ }^{\circ}\right)$ & $98.835(1)$ \\
$V\left(\AA^{3}\right)$ & $3708.78(11)$ \\
$Z$ & 4 \\
Formula weight $\left(\mathrm{g} . \mathrm{mol}^{-1}\right)$ & 998.45 \\
Space group $(\mathrm{No})$. & $C 2 / c\left(\mathrm{n}^{\circ} 15\right)$ \\
$\mathrm{D}_{\text {calc }}\left(\mathrm{g} . \mathrm{gm}^{-3}\right)$ & 1.788 \\
$\mu\left(\mathrm{mm}^{-1}\right)$ & 2.353 \\
$R(\%)$ & 3.93 \\
$R_{W}(\%)$ & 11.04 \\
$\mathrm{GoF}$ & 1.030 \\
$\mathrm{~N}^{\circ} \mathrm{CCDC}$ & 1495169 \\
\hline
\end{tabular}

\section{Energy Dispersive Spectroscopy.}

EDS measurements have been performed with a Hitachi TM-1000, Tabletop Microscope version 02.11 (Hitachi High-Technologies, Corporation Tokyo Japan) with EDS analysis system (SwiftED-TM, Oxford Instruments Link INCA). Samples were assembled on carbon discs, stuck on an aluminum stub fixed at $7 \mathrm{~mm}$ from EDX beam, with an angle of measurement of $22^{\circ}$. Reproducibility of the elemental analyses has been checked by repeating the measurements several times. These experiments support the monophasic character of the samples. 


\section{Solid state luminescent measurements.}

Solid state excitation and emission spectra have been measured on a Horiba JobinYvon Fluorolog III fluorescence spectrometer with a Xe lamp. Luminescence spectra were recorded between $300-750 \mathrm{~nm}$ at room temperature. Appropriate filters were used to remove the residual excitation laser light, the Rayleigh scattered light and harmonics from the emission spectra. The quantum yield were measured using a Jobin-Yvon integrating sphere $\left(\Phi=\left(\mathrm{E}_{\mathrm{c}}-\mathrm{E}_{\mathrm{a}}\right) /\left(\mathrm{L}_{\mathrm{a}}-\mathrm{L}_{\mathrm{c}}\right)\right.$ with $\mathrm{E}_{\mathrm{c}}$ being the integrated emission spectrum of the sample, $\mathrm{E}_{\mathrm{a}}$ - the integrated "blank" emission spectrum, $\mathrm{L}_{\mathrm{a}}$ - the "blank" absorption and $\mathrm{L}_{\mathrm{c}}$ - the sample absorption at the excitation wavelength). Luminescence decays have also been measured using this apparatus.

Comparative solid state luminescence spectra have been measured on a Perkin-Elmer LS-55 spectrometer between $450-700 \mathrm{~nm}$ under identical operating conditions and without turning the lamp off to ensure a valid comparison between the emission spectra. Slit widths for excitation and emission were $5 \mathrm{~nm}$.

Luminescence intensities of the samples in $\mathrm{Cd} \cdot \mathrm{m}^{-2}$ have been measured with a Gigahertz-Optik X1-1 optometer with an integration time of $200 \mathrm{~ms}$ on $1.5 \mathrm{~cm}^{2}$ pellets. The intensity of the UV flux, 2.5(1) W. $\mathrm{m}^{-2}$, has been measured with a VilberLourmat VLX-3W radiometer.

\section{Colorimetric measurements.}

The CIE (Commission Internationale de l'Eclairage) (x,y) emission color coordinates $^{[61,62]}$ were obtained using a MSU-003 colorimeter (Majantys) with the PhotonProbe 1.6.0 Software (Majantys). Color measurements: $2^{\circ}$, CIE 1931, step $5 \mathrm{~nm}$, under 
$312 \mathrm{~nm} \quad \mathrm{UV}$ light. $\mathrm{X}=k \times \int_{380 \mathrm{~nm}}^{780 \mathrm{~nm}} I_{\lambda} \times x_{\lambda}, \quad \mathrm{Y}=k \times \int_{380 \mathrm{~nm}}^{780 \mathrm{~nm}} I_{\lambda} \times y_{\lambda} \quad$ and $\quad \mathrm{Z}=k \times$

$\int_{380 n m}^{780 n m} I_{\lambda} \times z_{\lambda}$ with $\mathrm{k}$ - constant for the measurement system, $\mathrm{I}_{\lambda}$ - sample spectrum intensity and wavelength dependent, $\mathrm{x}_{\lambda}, \mathrm{y}_{\lambda}, \mathrm{z}_{\lambda}$ trichromatic values $\mathrm{x}=\mathrm{X} /(\mathrm{X}+\mathrm{Y}+\mathrm{Z}), \mathrm{y}=\mathrm{Y} /(\mathrm{X}+\mathrm{Y}+\mathrm{Z})$ and $\mathrm{z}=\mathrm{Z} /(\mathrm{X}+\mathrm{Y}+\mathrm{Z})$. Mean $\mathrm{x}, \mathrm{y}, \mathrm{z}$ values are given for each luminescent sample, which act as a light source. Standards from Phosphor Technology used, calibrated at $312 \mathrm{~nm}$ : red phosphor $\mathrm{Gd}_{2} \mathrm{O}_{2} \mathrm{~S}: \mathrm{Eu}(\mathrm{x}=0.667, \mathrm{y}=0.330)$ and green phosphor $\mathrm{Gd}_{2} \mathrm{O}_{2} \mathrm{~S}: \mathrm{Tb}(\mathrm{x}=0.328, \mathrm{y}=0.537)$.

\section{Coupled Thermal and IR analyses}

Coupled thermal (ATG/DSC) and IR analyses have been performed using a Perkin Elmer STA6000 thermal analyser coupled by a Perkin Elmer TL8000 transfer line to a Perkin Elmer Frontier IR spectrophotometer analyser. This allows simultaneous recording of the weight of the sample, the heat flux and the IR spectrum of the evolved gases versus temperature. Measurements were performed in ceramic crucibles under a nitrogen atmosphere between room temperature and $900^{\circ} \mathrm{C}$ with a $20^{\circ} \mathrm{C} \cdot \mathrm{min}^{-1}$ heating rate. At the end of the experiment, the compound was maintained for one hour at $900{ }^{\circ} \mathrm{C}$ under air atmosphere in order to complete the combustion.

\section{RESULTS AND DISCUSSION.}

\section{Structure and thermal analysis of $\left[\mathrm{La}_{2}(0-p d a)_{3}\left(\mathrm{H}_{2} \mathrm{O}\right)_{4}, 4 \mathrm{H}_{2} \mathrm{O}\right]_{\infty}(1)$}

The crystal structure of 1 is three-dimensional. The asymmetric unit contains one crystallographically independent lanthanum ion, one and a half ligands and four water molecules. The $\mathrm{La}^{3+}$ ion is ten-coordinated by eight oxygen atoms from five (o-pda) ligands and two oxygen atoms from coordination water molecules that form a slightly distorted icosahedron (Figure 2). 


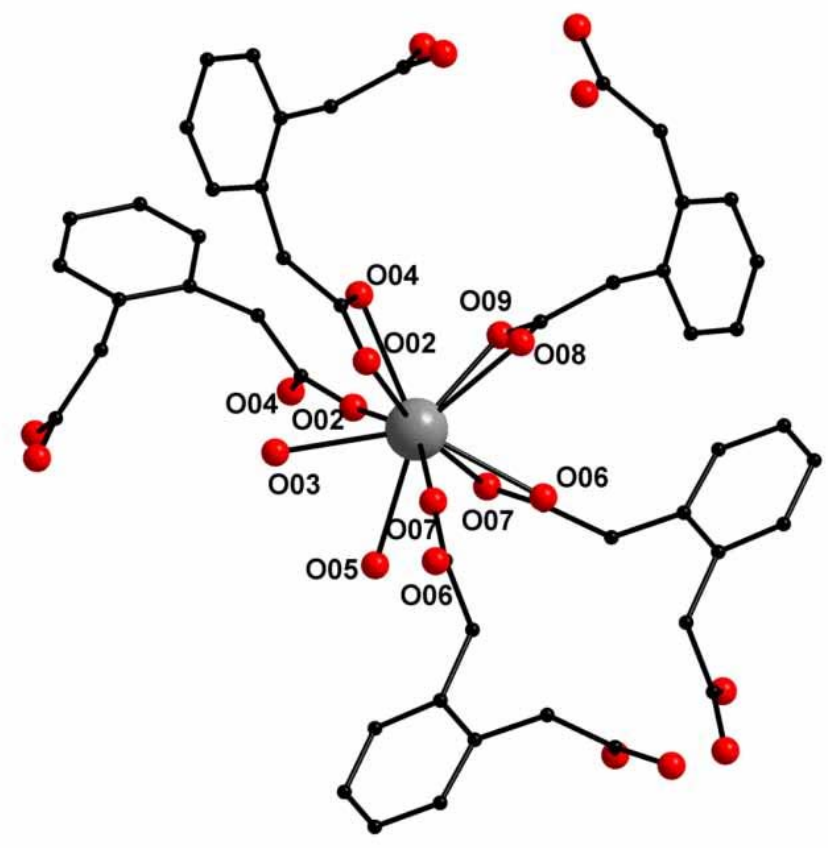

Figure 2. Lanthanum coordination in $\left[\mathrm{La}_{2}(\mathrm{o}-\mathrm{pda})_{3}\left(\mathrm{H}_{2} \mathrm{O}\right)_{4}, 4 \mathrm{H}_{2} \mathrm{O}\right]_{\infty}$. Hydrogen atoms have been omitted for clarity. Selected distances : La-O02 : $2.4824 \AA$; La-O07 $7^{\mathrm{ii}}: 2.7554 \AA$; La-O02 ${ }^{\mathrm{i}}$ : $2.6691 \AA$; La-O07 : $2.5021 \AA$; La-O04 : $2.6443 \AA$; La-O09 : $2.5694 \AA$; La-O05 : $2.6376 \AA$; La-O08 : $2.6141 \AA$; La-O03 : $2.6126 \AA$; La-O06: $2.5956 \AA$. (i) x, -y, -0.5+z; (ii) x, -y, $0.5+z$.

One out of the two independent ligands binds four $\mathrm{La}^{3+}$ ions and the other one binds three $\mathrm{La}^{3+}$ ions (Figure 3). This results in 1D inorganic chains running parallel to the $c$ axis, in which lanthanum coordination polyhedrons share vertexes (Figure 3). Adjacent lanthanum ions in the inorganic chains are connected to each other by two tridentate carboxylate clips from two different (o-pda) ${ }^{2-}$ ligands. Inorganic chains are bridged to each other by (o-pda) ${ }^{2-}$ ligands to form a 3D hybrid framework. 

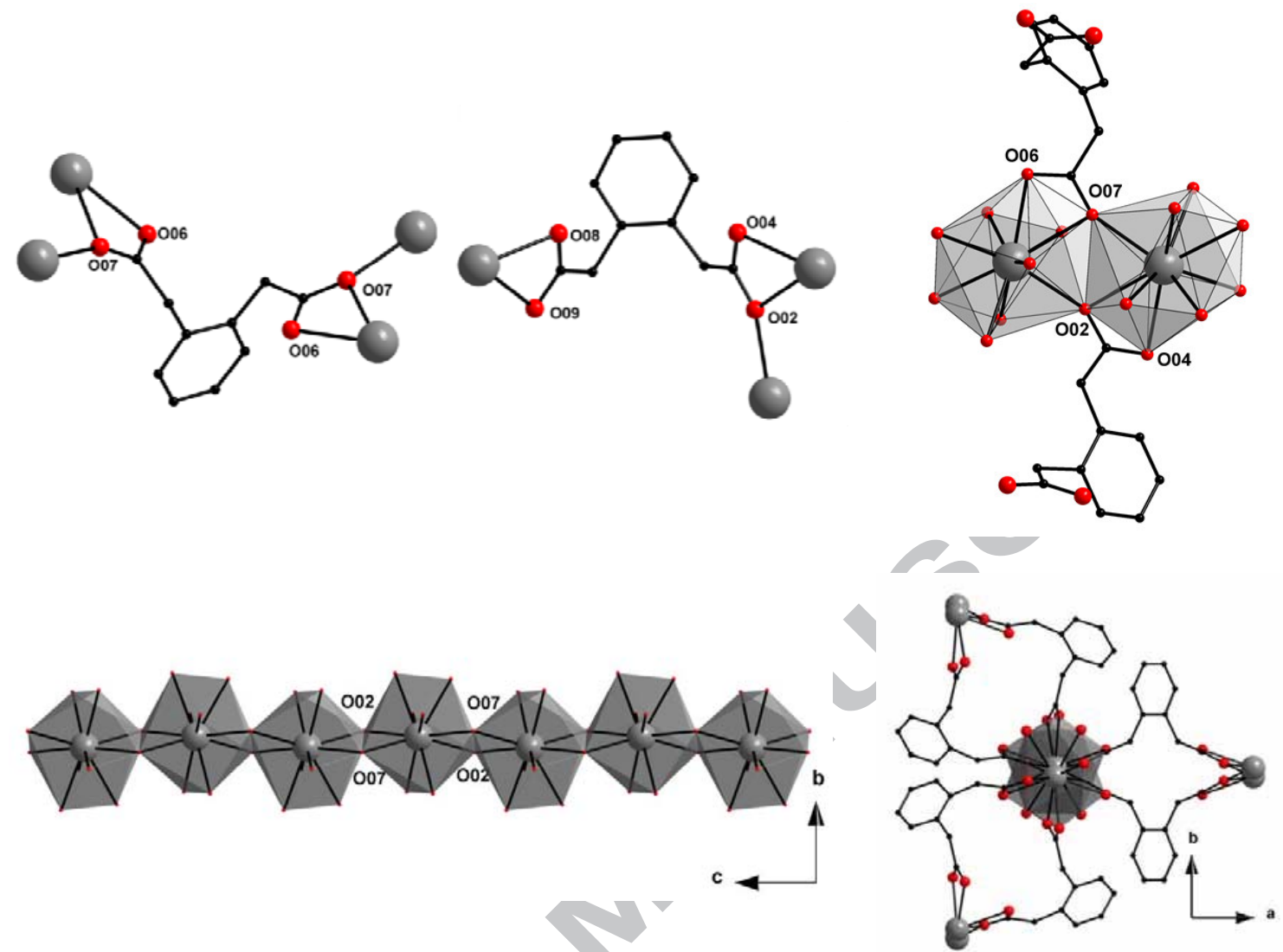

Figure 3. Top left: coordination modes of the two independent ligands in $\left[\mathrm{La}_{2}(\mathrm{O}-\right.$ pda $\left.)_{3}\left(\mathrm{H}_{2} \mathrm{O}\right)_{4}, 4 \mathrm{H}_{2} \mathrm{O}\right]_{\infty}$. Top right: Projection view of the bridges between $\mathrm{La}^{3+}$ ions in an inorganic chain. Bottom left: Projection view along the a axis of an inorganic chain in $\left[\mathrm{La}_{2}(\mathrm{O}-\right.$ pda $\left.)_{3}\left(\mathrm{H}_{2} \mathrm{O}\right)_{4}, 4 \mathrm{H}_{2} \mathrm{O}\right]_{\infty}$. Bottom right: Projection view along the $\mathrm{c}$ axis of an inorganic chain in $\left[\mathrm{La}_{2}(\mathrm{o}-\mathrm{pda})_{3}\left(\mathrm{H}_{2} \mathrm{O}\right)_{4}, 4 \mathrm{H}_{2} \mathrm{O}\right]_{\infty}$. Hydrogen atoms have been omitted for clarity.

This three-dimensional framework presents three types of channels, referenced as $\mathbf{A}, \mathbf{B}$ and $\mathbf{C}$ (Figure 4), that all run along the c axis. Channels $\mathbf{A}$ are free of crystallization water molecules because their walls are made of hydrophobic $\mathrm{C}-\mathrm{H}$ groups. On the opposite, channels $\mathbf{B}$ and $\mathbf{C}$ contain crystallization water molecules that are linked to the molecular skeleton via hydrogen bonds. 

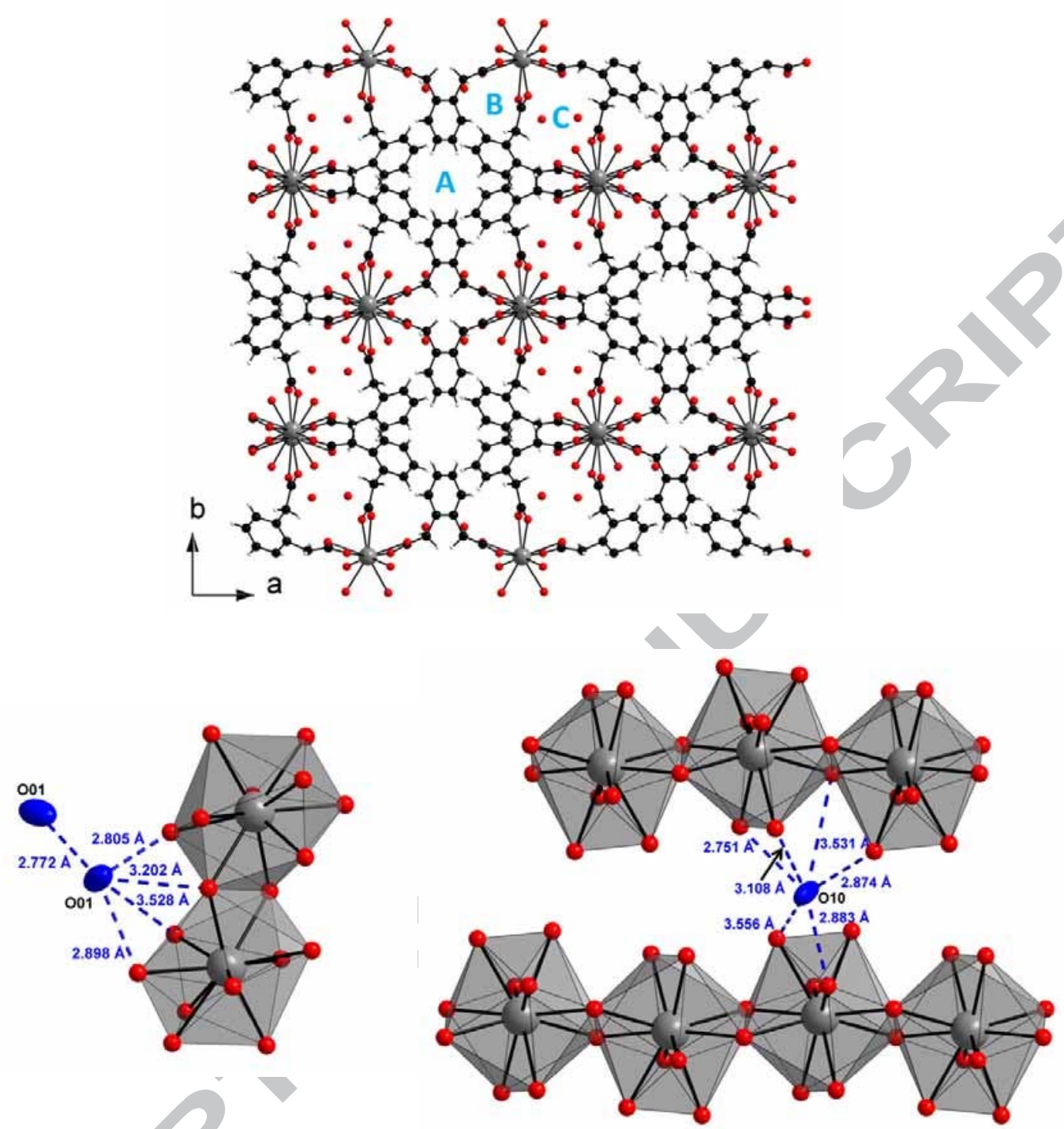

Figure 4. Top: Projection view along the $\mathrm{c}$ axis of the crystal packing of $\left[\mathrm{La}_{2}(\mathrm{o}-\right.$ pda $\left.)_{3}\left(\mathrm{H}_{2} \mathrm{O}\right)_{4}, 4 \mathrm{H}_{2} \mathrm{O}\right]_{\infty}$. Bottom: Scheme of the hydrogen bonds networks that bind crystallization water molecules (blue ellipsoids) to the molecular framework. Hydrogen bonds are symbolized by blue broken lines. O....O distances are indicated.

Thermo-gravimetric analysis (Figure S10) and temperature-dependent powder X-ray diffraction measurements (Figure S11) indicate that crystallization and coordination water molecules can be thermally removed without collapse of the molecular network. Therefore, it is possible by thermal activation to obtain a molecular framework with empty channels (Figure 5). The resulting dehydrated solid is stable up to $250^{\circ} \mathrm{C}$. Its theoritical porosity has 
been calculated by a known method ${ }^{[13,35,63]}$. This calculation indicates that the molecular framework cannot host molecules with a kinetic radius ${ }^{[64,65]}$ bigger than $0.8 \AA$.

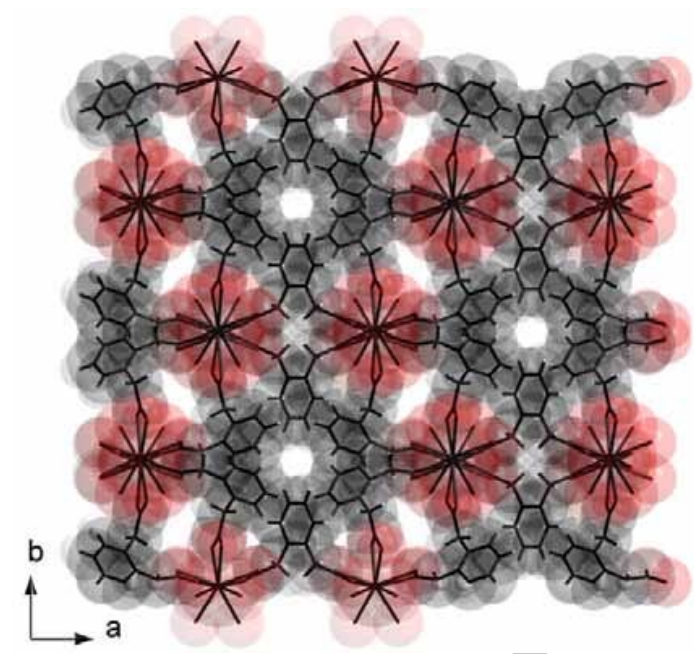

Figure 5. Projection view along the $\mathrm{c}$ axis of $\left[\mathrm{La}_{2}(\mathrm{o}-\mathrm{pda})_{3}\right]_{\infty}$. Sticks and space-filling representations have been superimposed in order to highlight the empty channels.

\section{Series (2): [ $\left.\mathrm{Ln}_{2}(\mathrm{o}-\mathrm{pda})_{3}\left(\mathrm{H}_{2} \mathrm{O}\right)_{2}, 2 \mathrm{H}_{2} \mathrm{O}\right]_{\infty}$ with $\mathrm{Ln}=\mathrm{Ce}-\mathrm{Nd}, \mathrm{Sm}-\mathrm{Lu}$ and $\mathrm{Y}$.}

Compounds (2) have been obtained in good yield as microcrystalline powders by direct precipitation. They are isostructural to the known crystal structure ${ }^{[44-47]}$ that has been described in the Introduction. Thermal stability of the compounds has been studied on the example of the Gd-containing compound by temperature-dependent powder X-ray diffraction (Figure S12) and by coupled DSC-IR analysis (Figures 6 and S5). 


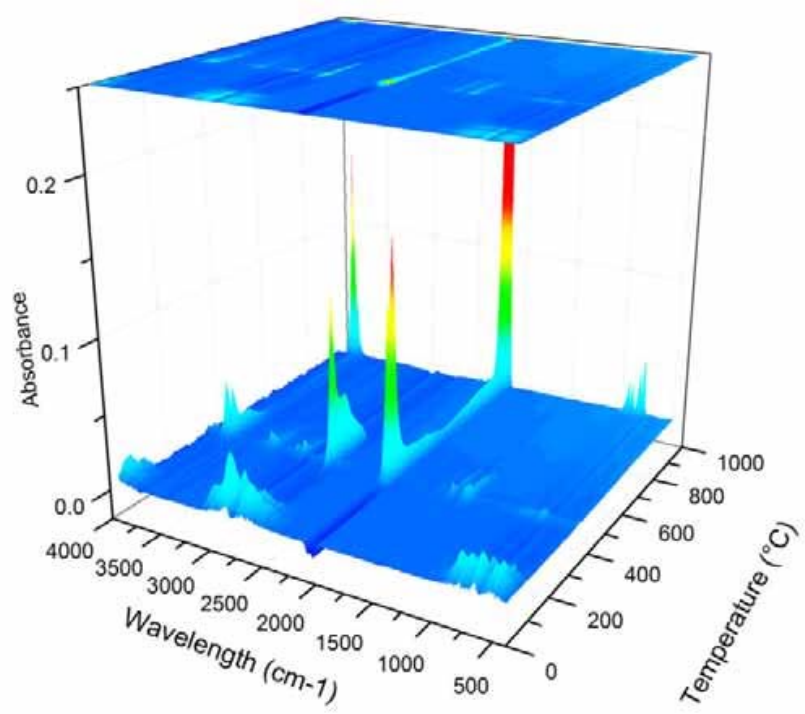

Figure 6. IR spectra versus temperature of the gases that evolve during thermal analysis of $\left[\mathrm{Gd}_{2}(\mathrm{o}-\mathrm{pda})_{3}\left(\mathrm{H}_{2} \mathrm{O}\right)_{2}, 2 \mathrm{H}_{2} \mathrm{O}\right]_{\infty}$

These experiments show a departure of the four coordination and crystallization water molecules per formula unit (exp.: $7.5 \%$ - calc.: $7.5 \%$ ) at approximately $100^{\circ} \mathrm{C}$. The departure of these water molecules does not modify the molecular skeleton that remains stable until almost $300^{\circ} \mathrm{C}$ (Figure S5). This quite high thermal stability can be related to the structural features. Indeed, the carboxylate groups of the ligands are crowded in the hydrated crystal structure (each of them is bound to two or three lanthanide ions) and cannot bind one more oxygen atom. Therefore the departure of the water molecules does not provoke structural reorganisation. When exposed to wet atmosphere the dehydrated phase reversibly binds water.

The molecular framework collapses progressively between $300-900^{\circ} \mathrm{C}$ with departure of an aromatic group (peaks around $2950 \mathrm{~cm}^{-1}$ ) and of an anhydride (characteristic peak at $1774 \mathrm{~cm}^{-1}$ ) (See Figures 6 and S13). Complete decomposition is achieved (with departure of $\mathrm{CO}_{2}$ and $\mathrm{H}_{2} \mathrm{O}$ ) when synthetic air is introduced (Figure $\mathrm{S} 13$ ).

Colorimetric coordinates and luminance under UV excitation have been measured for the compounds that involve lanthanide ion from Sm to Dy (Figure 7). 
$\mathbf{x}$

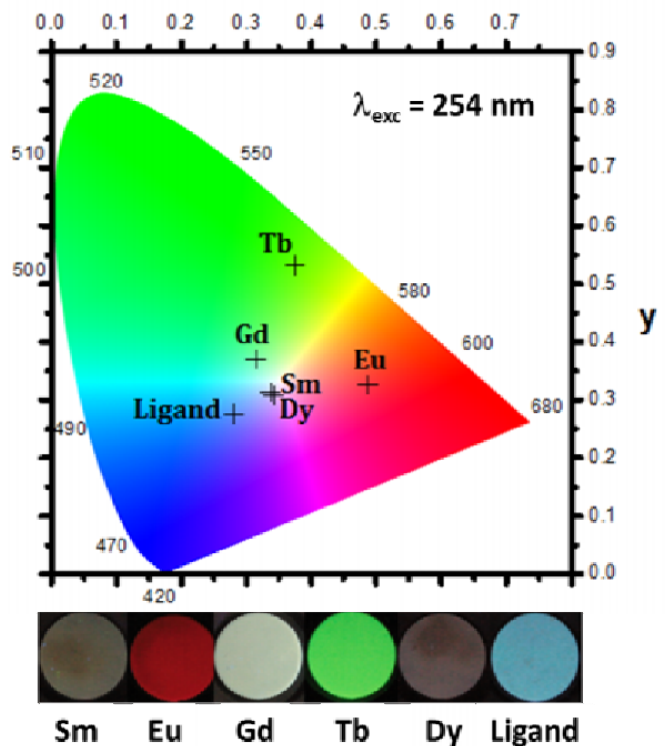

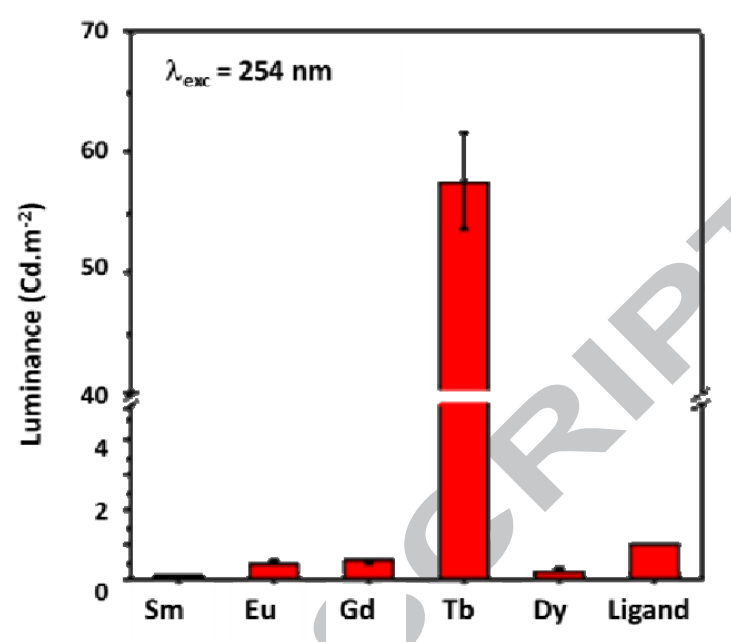

Figure 7. Colorimetric coordinates (left), luminance measurements (right) and pictures of pellets (bottom left) of $\left[\mathrm{Ln}_{2}(\mathrm{o}-\mathrm{pda})_{3}\left(\mathrm{H}_{2} \mathrm{O}\right)_{2}, 2 \mathrm{H}_{2} \mathrm{O}\right]_{\infty}$ with $\mathrm{Ln}=\mathrm{Sm}$-Dy under UV irradiation $\left(\lambda_{\text {exc }}=254 \mathrm{~nm}\right)$.

These measurements show that all the compounds show weak luminescence, except the Tb-based one which exhibits sizeable luminescence. Excitation and emission spectra have been recorded for both Eu- and Tb-containing compounds (Figure 8). 


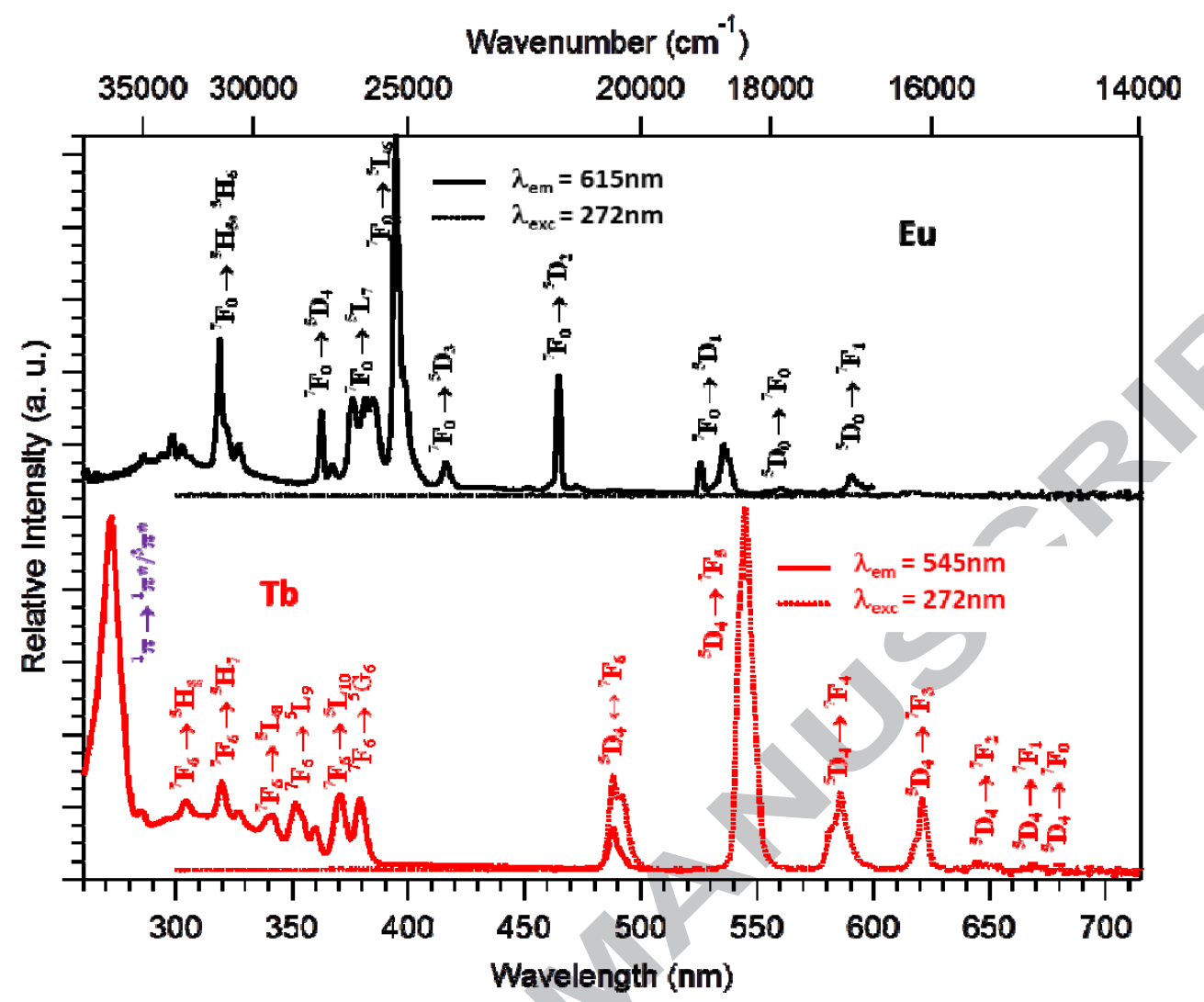

Figure 8. Top: Excitation $\left(\lambda_{\mathrm{em}}=615 \mathrm{~nm}\right)$ and emission $\left(\lambda_{\mathrm{exc}}=272 \mathrm{~nm}\right)$ spectra for $\left[\mathrm{Eu}_{2}(\mathrm{o}-\right.$ pda $\left.)_{3}\left(\mathrm{H}_{2} \mathrm{O}\right)_{2}, 2 \mathrm{H}_{2} \mathrm{O}\right]_{\infty}$. Bottom: Excitation $\left(\lambda_{\mathrm{em}}=545 \mathrm{~nm}\right)$ and emission $\left(\lambda_{\mathrm{exc}}=272 \mathrm{~nm}\right)$ spectra for $\left[\mathrm{Tb}_{2}(\mathrm{o}-\mathrm{pda})_{3}\left(\mathrm{H}_{2} \mathrm{O}\right)_{2}, 2 \mathrm{H}_{2} \mathrm{O}\right]_{\infty}$.

These experiments clearly show that the "antenna effect" can be observed for the Tbcontaining compound but not for the Eu-containing one. This suggests that the ligand energy levels are too high for allowing ligand-to-europium energy transfer $\left(\eta_{\mathrm{sens}}^{\mathrm{Eu}} \sim 0\right)$. On the opposite they are close enough from the $\mathrm{Tb}^{3+}$ receiving energy levels $\left({ }^{5} \mathrm{D}_{4}\right)$ for allowing a weak but sizeable ligand-to-terbium energy transfer $\left(\eta_{\text {sens }}^{\mathrm{Tb}} \neq 0\right)$. In order to support this hypothesis we have recorded luminescence spectra of both compounds under direct excitation of the lanthanide ion: $\lambda_{\text {exc }}=379 \mathrm{~nm}\left({ }^{6} \mathrm{~F}_{6} \rightarrow{ }^{5} \mathrm{G}_{6}\right)$ for $\left[\mathrm{Tb}_{2}(\mathrm{o}-\mathrm{pda})_{3}\left(\mathrm{H}_{2} \mathrm{O}\right)_{2}, 2 \mathrm{H}_{2} \mathrm{O}\right]_{\infty}$ and $\lambda_{\text {exc }}=395$ $\mathrm{nm}\left({ }^{7} \mathrm{~F}_{0} \rightarrow{ }^{5} \mathrm{~L}_{6}\right)$ for $\left[\mathrm{Eu}_{2}(\mathrm{o}-\mathrm{pda})_{3}\left(\mathrm{H}_{2} \mathrm{O}\right)_{2}, 2 \mathrm{H}_{2} \mathrm{O}\right]_{\infty}$ (Figure S14). Intrinsic quantum yields and luminescence decay lifetimes have been measured. Luminescence decays are mono- 
exponential. From Table 2, one can notice that the intrinsic quantum yield is low for the $\mathrm{Tb}$ containing compound and high for the Eu-containing compound.

Table 2. Intrinsic quantum yields and luminescence decay lifetimes

\begin{tabular}{llll}
\hline & $\lambda_{\text {exc }}(\mathrm{nm})$ & $\mathrm{Q}_{\mathrm{Ln}}^{\mathrm{Ln}}(\%)$ & $\tau_{\text {obs }}(\mathrm{ms})$ \\
\hline$\left[\mathrm{Tb}_{2}(\mathrm{o}-\mathrm{pda})_{3}\left(\mathrm{H}_{2} \mathrm{O}\right)_{2}, 2 \mathrm{H}_{2} \mathrm{O}\right]_{\infty}$ & 379 & $4.0(3)$ & $1.46(3)$ \\
{$\left[\mathrm{Eu}_{2}(\mathrm{o}-\mathrm{pda})_{3}\left(\mathrm{H}_{2} \mathrm{O}\right)_{2}, 2 \mathrm{H}_{2} \mathrm{O}\right]_{\infty}$} & 395 & $24(2)$ & $0.69(1)$ \\
\hline
\end{tabular}

To estimate the efficiency of the metal-to-metal energy transfer, two series of heterolanthanide compounds have been synthesised: $\left[\mathrm{Tb}_{2 \mathrm{x}} \mathrm{Gd}_{2-2 \mathrm{x}}(\mathrm{o}-\mathrm{pda})_{3}\left(\mathrm{H}_{2} \mathrm{O}\right)_{2}, 2 \mathrm{H}_{2} \mathrm{O}\right]_{\infty}$ and $\left[\mathrm{Tb}_{2} \mathrm{Eu}_{2-2 \mathrm{x}}(\mathrm{O}-\mathrm{pda})_{3}\left(\mathrm{H}_{2} \mathrm{O}\right)_{2}, 2 \mathrm{H}_{2} \mathrm{O}\right]_{\infty}$ with $0 \leq \mathrm{x} \leq 1$. These compounds are isostructural (See Experimental Section). Their luminescence spectra have been recorded with a $272 \mathrm{~nm}$ excitation (Figure 9). 


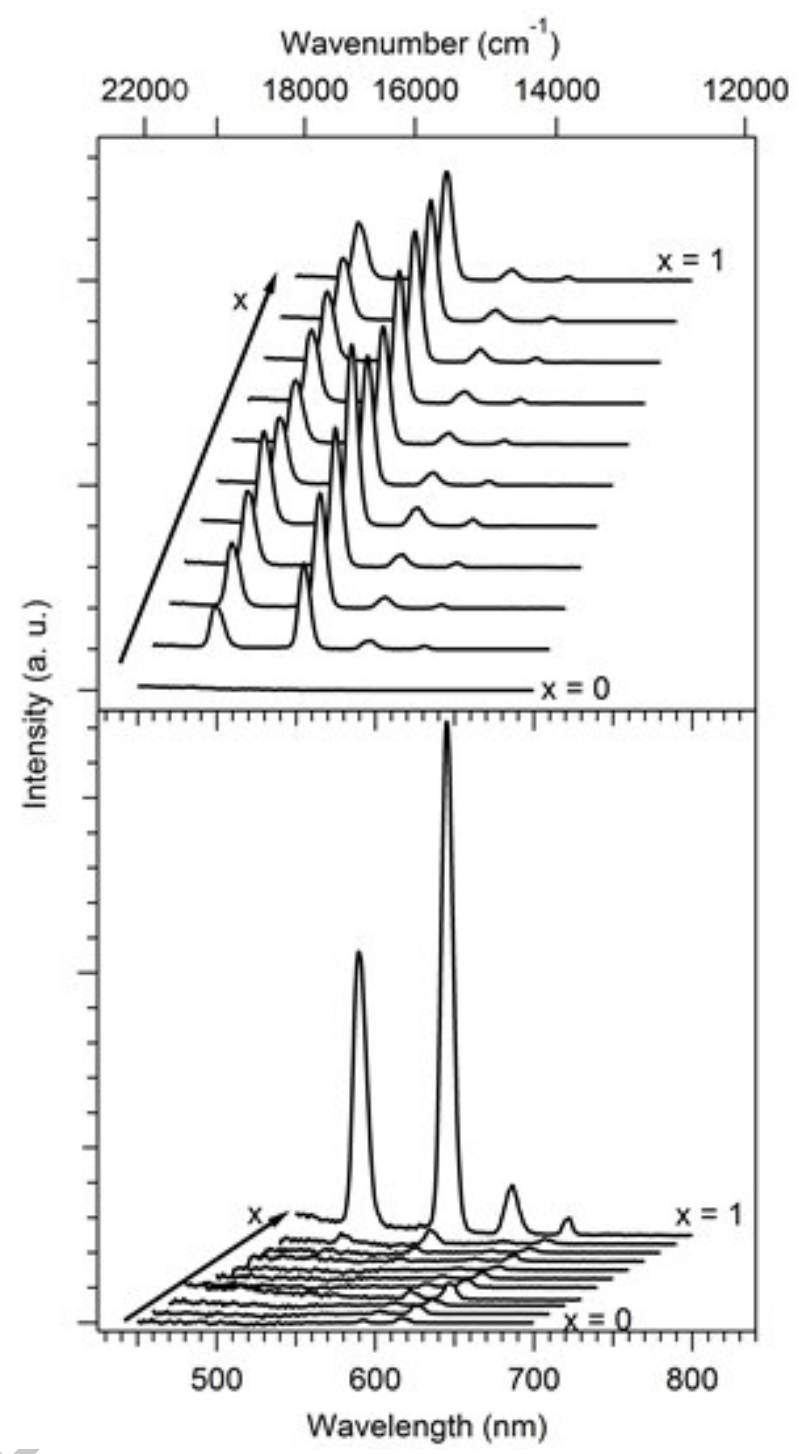

Figure 9. Emission spectra versus $\mathrm{x}$ for $\left[\mathrm{Tb}_{2 \mathrm{x}} \mathrm{Gd}_{2-2 \mathrm{x}}(\mathrm{o}-\mathrm{pda})_{3}\left(\mathrm{H}_{2} \mathrm{O}\right)_{2}, 2 \mathrm{H}_{2} \mathrm{O}\right]_{\infty}$ (top) and $\left[\mathrm{Tb}_{2 \mathrm{x}} \mathrm{Eu}_{2-2 \mathrm{x}}(\mathrm{o}-\mathrm{pda})_{3}\left(\mathrm{H}_{2} \mathrm{O}\right)_{2}, 2 \mathrm{H}_{2} \mathrm{O}\right]_{\infty}$ (bottom) with $0 \leq \mathrm{x} \leq 1 . \lambda_{\text {exc }}=272 \mathrm{~nm}$. The spectra are shifted for clarity.

Emission intensity of the $\left[\mathrm{Tb}_{2 \mathrm{x}} \mathrm{Gd}_{2-2 \mathrm{x}}(\mathrm{o}-\mathrm{pda})_{3}\left(\mathrm{H}_{2} \mathrm{O}\right)_{2}, 2 \mathrm{H}_{2} \mathrm{O}\right]_{\infty}$ compounds presents a maximum for $\mathrm{x} \approx 0.4$. This is in agreement with the crystal structure. Indeed, it is well known ${ }^{[66]}$ that intermetallic energy transfer becomes inefficient when the inter-metallic distance is greater than $10 \AA$. This crystal structure can be described on the basis of a monodimensional inorganic sub-lattices that spread along the $c$ axis (Figure 10). Inter-lanthanide distances (Table 3 ) between the inorganic chains are long (between $7.8 \AA$ and $11.4 \AA$ ) but 
within the chains are short $(4.0 \AA)$. Therefore, in the compound $\left[\operatorname{Tb}_{0.8} \operatorname{Gd}_{1.2}(0\right.$ pda $\left.)_{3}\left(\mathrm{H}_{2} \mathrm{O}\right)_{2}, 2 \mathrm{H}_{2} \mathrm{O}\right]_{\infty}$, the mean distance ${ }^{[32,52]}$ between two neighbouring terbium ions that belong to the same inorganic chain is about $10 \AA$.
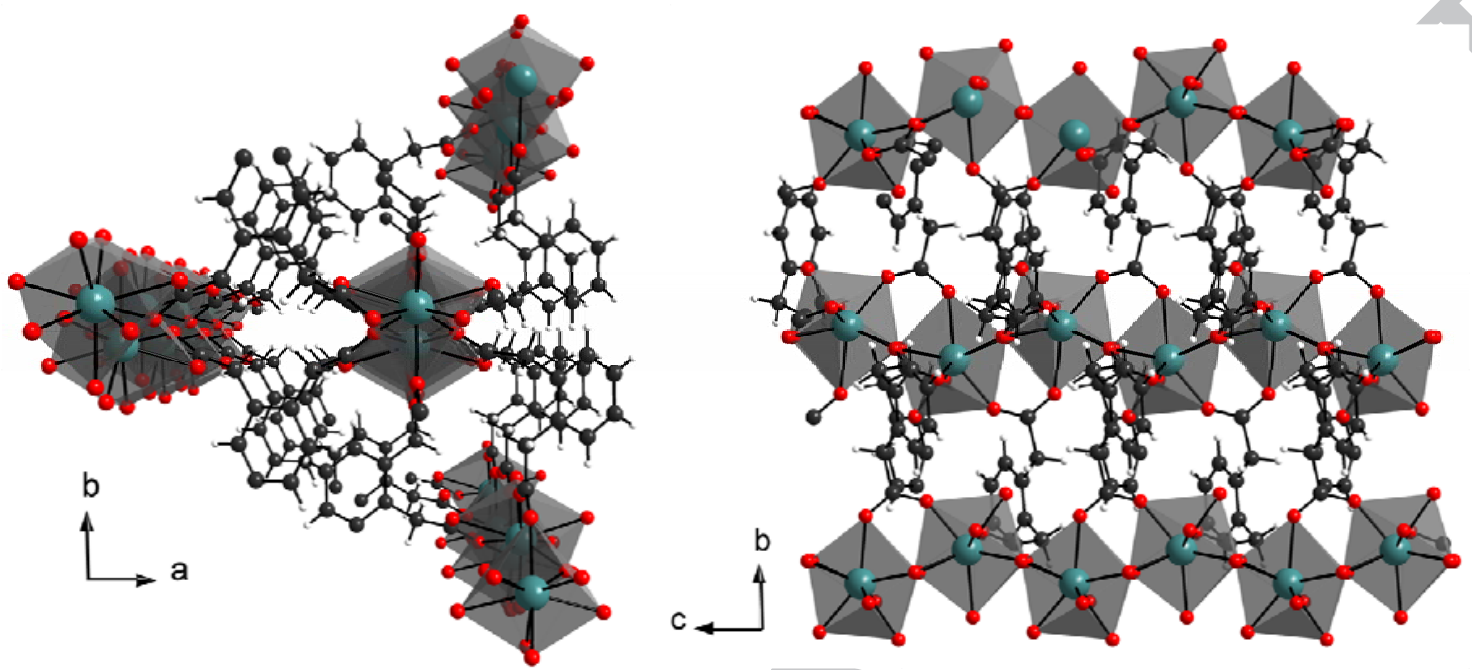

Figure 10. Left: Perspective view along the c axis in $\left[\mathrm{Tb}_{2}(\mathrm{o}-\mathrm{pda})_{3}\left(\mathrm{H}_{2} \mathrm{O}\right)_{2}, 2 \mathrm{H}_{2} \mathrm{O}\right]_{\infty}$. Right: Projection view along the a axis in $\left[\mathrm{Tb}_{2}(\mathrm{o}-\mathrm{pda})_{3}\left(\mathrm{H}_{2} \mathrm{O}\right)_{2}, 2 \mathrm{H}_{2} \mathrm{O}\right]_{\infty}$.

\begin{tabular}{cccc}
\hline \multicolumn{5}{c}{ Table 3. Selected inter-lanthanide distances } \\
\hline Atom 1 & Atom 2 & Symmetry 2 & Distance $(\AA)$ \\
\hline $\mathrm{Tb}$ & $\mathrm{Tb}$ & $\mathrm{x}, 1-\mathrm{y}, 0.5+\mathrm{z}$ & $4.0190(2)$ \\
$\mathrm{Tb}$ & $\mathrm{Tb}$ & $0.5-\mathrm{x}, 0.5-\mathrm{y},-\mathrm{z}$ & $7.8206(3)$ \\
$\mathrm{Tb}$ & $\mathrm{Tb}$ & $0.5-\mathrm{x}, 0.5-\mathrm{y},-1-\mathrm{z}$ & $11.4593(3)$ \\
$\mathrm{Tb}$ & $\mathrm{Tb}$ & $0.5-\mathrm{x},-0.5+\mathrm{y},-0.5-\mathrm{z}$ & $9.9645(3)$ \\
$\mathrm{Tb}$ & $\mathrm{Tb}$ & $-\mathrm{x}, \mathrm{y}, 0.5-\mathrm{z}$ & $10.1165(4)$ \\
$\mathrm{Tb}$ & $\mathrm{Tb}$ & $-\mathrm{x}, 1-\mathrm{y},-\mathrm{z}$ & $9.4247(4)$ \\
$\mathrm{Tb}$ & $\mathrm{Tb}$ & $-\mathrm{x}, \mathrm{y},-0.5-\mathrm{z}$ & $10.0931(4)$ \\
$\mathrm{Tb}$ & $\mathrm{Tb}$ & $0.5-\mathrm{x}, 0.5+\mathrm{y}, 0.5-\mathrm{z}$ & $9.3810(3)$ \\
$\mathrm{Tb}$ & $\mathrm{Tb}$ & $0.5-\mathrm{x}, 1.5-\mathrm{y},-\mathrm{z}$ & $9.9785(3)$ \\
$\mathrm{Tb}$ & $\mathrm{Tb}$ & $0.5-\mathrm{x},-0.5+\mathrm{y}, 0.5-\mathrm{z}$ & $9.3810(3)$ \\
$\mathrm{Tb}$ & $\mathrm{Tb}$ & $0.5-\mathrm{x}, 0.5+\mathrm{y},-0.5-\mathrm{z}$ & $9.9645(3)$ \\
\hline
\end{tabular}

Emission intensities of the compounds $\left[\mathrm{Tb}_{2 \mathrm{x}} \mathrm{Eu}_{2-2 \mathrm{x}}(\mathrm{o}-\mathrm{pda})_{3}\left(\mathrm{H}_{2} \mathrm{O}\right)_{2}, 2 \mathrm{H}_{2} \mathrm{O}\right]_{\infty}$ with $0 \leq \mathrm{x} \leq$ 1 become very weak as soon as $\mathrm{x}$ is different from one. Even when $\mathrm{x}=0.9$, the terbium luminescence almost vanishes and the europium one becomes dominant. This suggests an efficient terbium-to-europium energy transfer. 


\section{CONCLUSION AND OUTLOOK.}

A new crystal structure of a lanthanide coordination polymer with 1,2phenylenediacetate ligand has been described.

Luminescent properties of homo- and hetero-lanthanide compounds isostructural to the known crystal structure of $\left[\mathrm{Tb}_{2}(\mathrm{o}-\mathrm{pda})_{3}\left(\mathrm{H}_{2} \mathrm{O}\right)_{2}, 2 \mathrm{H}_{2} \mathrm{O}\right]_{\infty}$ have been studied. ${ }^{[47]}$ This study highlights the role of the conjugation of the ligand in the efficiency of the so-called "antenna effect". On the other hand, it also shows that the presence of a $-\mathrm{CH}_{2}-$ group has no effect on the efficiency of the intermetallic energy transfer. This can help in the design of luminescent lanthanide coordination polymers with complex luminescent properties.

\section{ACKNOWLEDGEMENT.}

The French Cooperation Agency in Senegal is acknowledged for financial support.

M. Vincent Roquet is acknowledged for coupled ATG/DSC/IR measurements.

The CDIFX of Rennes is acknowledged for single crystal X-ray diffraction data collection. 


\section{REFERENCES}

1. Li, B.; Wen, H.-M.; Cui, Y.; Qian, G.; Chen, B., Prog. Polym. Sci. 2015, 48, 40-84.

2. Cui, Y.; Li, B.; He, H.; Zhou, W.; Chen, B.; Qian, G., Accounts Chem. Res. 2016, 49, 483-493.

3. Guillou, O.; Daiguebonne, C.; Calvez, G.; Bernot, K., Accounts Chem. Res. 2016, 49, 844-856.

4. Eddaoudi, M.; Kim, J.; Rosi, N.; Vodak, D.; Wachter, J.; O'Keeffe, M.; Yaghi, O. M., Science 2002, 295, 469-472.

5. Reneike, T. M.; Eddaoudi, M.; O'Keeffe, M.; Yaghi, O. M., Angew. Chem. Int. Ed. 1999, 38, 2590-2594.

6. Reneike, T. M.; Eddaoudi, M.; Fehr, M.; Kelley, D.; Yaghi, O. M., J. Am. Chem. Soc. 1999, 121, 1651-1657.

7. Yaghi, O. M.; Li, G.; Li, H., Nature 1995, 378, 703-706.

8. Yaghi, O. M.; Li, H. L., J. Am. Chem. Soc. 1995, 117, 10401-10402.

9. Férey, G.; Serre, C.; Mellot-Draznieks, C.; Millange, F.; Surblé, S.; Dutour, J.; Margiolaki, I., Angew. Chem. Int. Ed. 2004, 43, 6296-6301.

10. Férey, G.; Mellot-Draznieks, C.; Serre, C.; Millange, F., Accounts Chem. Res. 2004, 38, $217-$ 225.

11. Almeida Paz, F. A.; Klinowski, J.; Vilela, S. M. F.; Tome, J. P. C.; Cavaleiro, J. A. S.; Rocha, J., Chem. Soc. Rev. 2012, 41, 1088-1110.

12. Luo, Y.; Calvez, G.; Freslon, S.; Daiguebonne, C.; Roisnel, T.; Guillou, O., Inorg. Chim. Acta 2011, 368, 170-178.

13. Kustaryono, D.; Kerbellec, N.; Calvez, G.; Daiguebonne, C.; Guillou, O., Cryst. Growth Des. 2010, 10, 775-781.

14. Lee, J.; Farha, O. K.; Roberts, J.; Scheidts, A.; Nguyen, S. T.; Hupp, J. T., Chem. Soc. Rev. 2009, 38, 1450-1459.

15. Hamon, L.; Llewellyn, P. L.; Devic, T.; Ghoufi, A.; Clet, G.; Guillerm, V.; Pirngruber, G. D.; Maurin, G.; Serre, C.; Driver, G.; van Beek, W.; Jolimaitre, E.; Vimont, A.; Daturi, M.; Férey, G., J. Am. Chem. Soc. 2009, 131, 17490-17499.

16. Cui, Y.; Yue, Y.; Qian, G.; Chen, B., Chem. Rev. 2012, 1126-1162.

17. Cui, Y.; Xu, H.; Yue, Y.; Guo, Z.; Yu, J.; Chen, Z.; Gao, J.; Yang, Y.; Qian, G.; Chen, B., J. Am. Chem. Soc. 2012, 134, 3979-3982.

18. Daiguebonne, C.; Kerbellec, N.; Guillou, O.; Bünzli, J. C. G.; Gumy, F.; Catala, L.; Mallah, T.; Audebrand, N.; Gérault, Y.; Bernot, K.; Calvez, G., Inorg. Chem. 2008, 47, 3700-3708

19. Daiguebonne, C.; Kerbellec, N.; Gérault, Y.; Guillou, O., J. Alloys Compd. 2008, 451, 372-376.

20. Lan, A. J.; Li, K. H.; Wu, H. H.; Olson, D. H.; Emge, T. J.; Ki, W.; Hong, M. C.; Li, J., Angew. Chem. Int. Ed. 2009, 48, 2334-2338.

21. Dang, S.; Min, X.; Yang, W.; Yi, F. Y.; You, H.; Sun, Z. M., Chem. - Eur. J. 2013, 19, $17172-$ 17179.

22. Binnemans, K., Chem. Rev. 2009, 109, 4283-4374.

23. Liu, Y.; Sun, L.; Liu, J.; Peng, Y.-X.; Ge, X.; Shi, L.; Huang, W., Dalton Trans. 2015, 44, 237-246.

24. Feng, J.; Zhang, H. J., Chem. Soc. Rev. 2013, 42, 387-410.

25. Sun, L.-N.; Yu, J.-B.; Zhang, H. J.; Meng, Q. G.; Ma, E.; Peng, C.-Y.; Yang, K.-Y., Micropor. Mesopor. Mat. 2007, 98, 156-165.

26. Calvez, G.; Bernot, K.; Guillou, O.; Daiguebonne, C.; Caneschi, A.; Mahé, N., Inorg. Chim. Acta 2008, 361, 3997-4003.

27. Jeon, J. R.; Clérac, R., Dalton Trans. 2012, 41, 9569-9586.

28. Jung, J.; Le Natur, F.; Cador, O.; Pointillart, F.; Calvez, G.; Daiguebonne, C.; Guillou, O.; Guizouarn, T.; Le Guennic, B.; Bernot, K., Chem. Comm. 2014, 50, 13346-13348.

29. Sessoli, R.; Powell, A. K., Coord. Chem. Rev. 2009, 253, 2328-2341.

30. Freslon, S.; Luo, Y.; Calvez, G.; Daiguebonne, C.; Guillou, O.; Bernot, K.; Michel, V.; Fan, X., Inorg. Chem. 2014, 53, 1217-1228. 
31. Fan, X.; Freslon, S.; Daiguebonne, C.; Calvez, G.; Le Polles, L.; Bernot, K.; Guillou, O., J. Mater. Chem. C 2014, 5510-5525.

32. Haquin, V.; Etienne, M.; Daiguebonne, C.; Freslon, S.; Calvez, G.; Bernot, K.; Le Polles, L.; Ashbrook, S. E.; Mitchell, M. R.; Bünzli, J. C. G.; Guillou, O., Eur. J. Inorg. Chem. 2013, 3464-3476.

33. Le Natur, F.; Calvez, G.; Daiguebonne, C.; Guillou, O.; Bernot, K.; Ledoux, J.; Le Polles, L.; Roiland, C., Inorg. Chem. 2013, 52, 6720-6730.

34. Luo, Y.; Calvez, G.; Freslon, S.; Bernot, K.; Daiguebonne, C.; Guillou, O., Eur. J. Inorg. Chem. 2011, 3705-3716.

35. Qiu, Y.; Daiguebonne, C.; Liu, J.; Zeng, R.; Kerbellec, N.; Deng, H.; Guillou, O., Inorg. Chim. Acta 2007, 360, 3265-3271.

36. Fan, X.; Freslon, S.; Daiguebonne, C.; Le Polles, L.; Calvez, G.; Bernot, K.; Guillou, O., Inorg. Chem. 2015, 54, 5534-5546.

37. Deluzet, A.; Guillou, O., Acta Crystallogr. C 2003, 59, m277-m279.

38. Luo, Y.; Bernot, K.; Calvez, G.; Freslon, S.; Daiguebonne, C.; Guillou, O.; Kerbellec, N.; Roisnel, T., Cryst. Eng. Comm. 2013, 15, 1882-1896.

39. Daiguebonne, C.; Gérault, Y.; Guillou, O.; Lecerf, A.; Boubekeur, K.; Batail, P.; Kahn, M.; Kahn, O., J. Alloys Compd. 1998, 275-277, 50-53.

40. Yang, G.-P.; Wang, Y.-Y.; Zhang, W.-H.; Fu, A.-Y.; Liu, R.-T.; Lermontova, E. K.; Shi, Q.-Z., Cryst. Eng. Comm. 2010, 12, 1509-1517.

41. Murray, N. H.; Farnum, G. A.; LaDuca, R. L., Z. Anorg. Allg. Chem. 2013, 639, 2162-2170.

42. Blake, K. M.; Banisafar, A.; LaDuca, R. L., Inorg. Chim. Acta 2011, 373, 201-210.

43. He, Q.-F.; Li, D.-S.; Zhao, J.; Ke, X.-J.; Li, C.; Mou, Y.-Q., Inorg. Chem. Comm. 2011, 14, 578-

583.

44. Chen, L.-J.; Chen, X.; Hou, Q.-B.; Yang, M.-X.; Lin, S., Chin. J. Inorg. Chem. 2014, 30, 786-792.

45. Wang, C.-Y.; Wu, X.-S.; Li, X., Chin. J. Inorg. Chem. 2008, 24, 781-784.

46. Zhang, M.-L.; Chen, X.-L.; Wang, J.-J., Chin. J. Struct. Chem. 2014, 33, 935-941.

47. Li, X.; Wang, C.; Zheng, X.; Zou, Y., J. Coord. Chem. 2008, 61, 1127-1136.

48. Daiguebonne, C.; Deluzet, A.; Camara, M.; Boubekeur, K.; Audebrand, N.; Gérault, Y.; Baux, C.; Guillou, O., Cryst. Growth Des. 2003, 3, 1015-1020.

49. Desreux, J. F., In Lanthanide Probes in Life, Chemical and Earth Sciences, Choppin, G. R.; Bünzli, J. C. G., Eds. Elsevier: Amsterdam, 1989; Vol. Elsevier, p 43.

50. Henisch, H. K., Crystals in Gels and Liesegang Rings. Cambridge University Press: Cambridge, 1988.

51. Henisch, H. K.; Rustum, R., Crystal Growth in Gels. The Pennsylvania State University Press: 1970; p 1-196.

52. Kerbellec, N.; Kustaryono, D.; Haquin, V.; Etienne, M.; Daiguebonne, C.; Guillou, O., Inorg. Chem. 2009, 48, 2837-2843.

53. Roisnel, T.; Rodriguez-Carjaval, J., J. Mater. Sci. Forum 2001, 378, 118-123.

54. Kraus, W.; Nolze, G., J. Appl. Crystallogr. 1996, 29, 301-303.

55. Le Bail, A., Powder Diffr. 2004, 19, 249-254.

56. Shinley, R. The CRYSFIRE system for automatic powder indexing.

57. Sheldrick, G. M., Acta Crystallogr. A 2008, 64, 112-122.

58. Altomare, A.; Burla, M. C.; Camalli, M.; Carrozzini, B.; Cascarano, G.; Giacovazzo, C.; Guagliardi, A.; Moliterni, A. G. G.; Polidori, G.; Rizzi, A. C., J. Appl. Crystallogr. 1999, 32, 339-340.

59. Sheldrick, G. M.; Schneider, T. R., Macromol. Crystallogr. B 1997, 319-343.

60. Farrugia, L. J., J. Appl. Crystallogr. 2012, 45, 849-854.

61. Wyszecki, G., Colorimetry. In Handbook of Optics, Driscoll, W. G.; Vaughan, W., Eds. Mac Graw-Hill Book Company: New-York, 1978; pp 1-15.

62. CIE, International Commission on Illumination - Technical report. CIE: 1995; Vol. 13-3, p 16.

63. Kerbellec, N.; Daiguebonne, C.; Bernot, K.; Guillou, O.; Le Guillou, X., J. Alloys Compd. 2008, 451, 377-383. 
64. Rosi, N.; Kim, J.; Eddaoudi, M.; Chen, B.; O'Keeffe, M.; Yaghi, O. M., J. Am. Chem. Soc. 2005, $127,1504-1518$.

65. Albrecht, E.; Baum, G.; Bellunato, T.; Bressan, A.; Dall Torre, S.; D'Ambrosio, C.; Davenport, M.; Dragicevic, M.; Duarte Pinto, S.; Fauland, P.; Ilie, S.; Lenzen, G.; Pagano, P.; Piedigrossi, D.; Tessarotto, F.; Ullaland, O., Nucl. Instrum. Methods 2003, A510, 262-272.

66. Bünzli, J. C. G.; Eliseeva, S. V., Basics of lanthanide photophysics. In Lanthanide Luminescence, Hänninen, P.; Härmä, H., Eds. Springer Berlin Heidelberg: 2010; pp 1-45. 
Reactions in water between lanthanide chlorides and di-sodium 1,2-phenylenediacetate, lead to two families of coordination polymers $\left[\mathrm{La}_{2}(\mathrm{o}-\mathrm{pda})_{3}\left(\mathrm{H}_{2} \mathrm{O}\right)_{4}, 4 \mathrm{H}_{2} \mathrm{O}\right]_{\infty}(1)$ and $\left[\operatorname{Ln}_{2}(\mathrm{o}-\mathrm{pda})_{3}\left(\mathrm{H}_{2} \mathrm{O}\right)_{2}, 2 \mathrm{H}_{2} \mathrm{O}\right]_{\infty}(2)$ for $\mathrm{Ln}=\mathrm{Ce}-\mathrm{Nd}, \mathrm{Sm}-\mathrm{Lu}$ and Y. Crystal structure of (1) is described. Luminescence properties of Eu and Tb compounds have been studied.

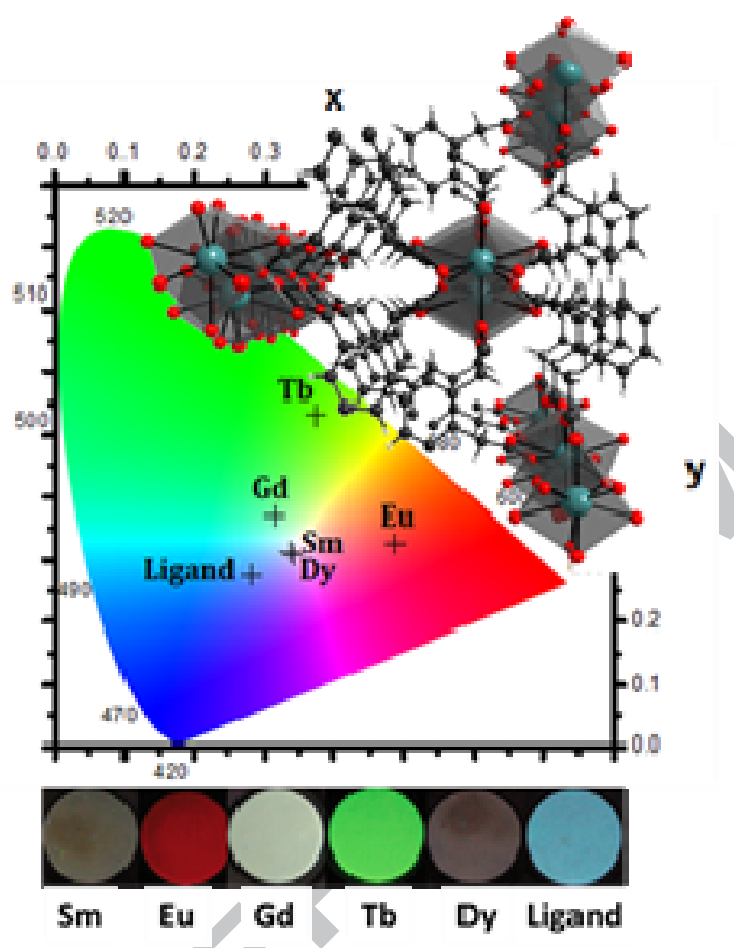




\section{Highlights}

Crystal structure of a new lanthanide-based coordination polymer [ $\mathrm{La}_{2}(\mathrm{O}-$ pda $\left.)_{3}\left(\mathrm{H}_{2} \mathrm{O}\right)_{4}, 4 \mathrm{H}_{2} \mathrm{O}\right]_{\infty}$, is described.

Luminescence properties of a series of lanthanide coordination polymers with1,2phenylenediacetate are described.

Thermal properties of lanthanide coordination polymers with1,2-phenylenediacetate are discussed. 